\title{
Seeing Covid-19 through a subprime crisis lens: How structural and institutional racism have shaped 21st-Century crises in the UK and the US
}

\author{
Frank Curry, Gary Dymski, Tanita J. Lewis, and Hanna K. Szymborska
}

28 Oct 2021

\begin{abstract}
This special issue aims to use historical examples to gain insight into the socio-economic impact of, and possibilities of recovery from, the Covid-19 pandemic for Black communities. We approach this question by comparing the impact of the pandemic on Black Britons in the United Kingdom with that of the 2008 subprime crisis on Black Americans. We find that, in both cases, a pattern of racially asymmetric losses and race-neutral policy responses that have systematically ignored the disparate losses borne by Black and racial/ethnic minority communities. Both patterns are manifestations of these countries' institutional racism. Relying on insights from stratification economics, and use of the concept of 'racial formation' introduced by Harold Baron in 1985, we show how these nations' historical relationships to slavery and imperialism have led to different structures of racial control. Our review of UK government policy includes a critique of the March 2021 report of the UK Commission on Race and Ethnic Disparities.
\end{abstract}

Keywords: institutional racism; Covid-19; subprime crisis;

Black Britons; Commission on Race and Ethnic Disparities

JEL Codes: J15, J18, D63, H12

Professional affiliations and contact information:

Curry: St. Paul's Research Institute, London, UK; Email: frank.curry@gmail.com

Dymski: Leeds University Business School, University of Leeds, Leeds, UK; Email: g.dymski@leeds.ac.uk

Lewis: Leeds University Business School, University of Leeds, Leeds, UK; Email: tanita.lewis@,virginmedia.com

Szymborska: Birmingham City Business School, Birmingham City University, Birmingham, UK; Email: hanna.szymborska@bcu.ac.uk (corresponding author) 


\section{Seeing Covid-19 through a subprime crisis lens: How structural and institutional racism have shaped $21^{\text {st }}$-Century crises in the UK and the US}

\section{Introduction}

For Black Britons and Black Americans, the Covid-19 pandemic has repeated a pattern established in the subprime crisis: while these communities have been most infected by the virus and suffered the highest rates of loss, they have not been prioritized in UK and US policy responses. ${ }^{1}$ In the subprime crisis, even while predatory credit and high-cost mortgage loans flooded minority - and especially Black American - communities, the megabanks that had profited from these markets were bailed out. And while the Black Lives Matter (BLM) movement has focused attention on racism's dire consequences during the Covid-19 crisis, the documented excess vulnerability of minority communities has not led to targeted policy responses. This was to be expected from a Trump administration that embraced a white nationalist agenda. But the UK government's policy response was aggressively tone-deaf. In response to BLM protests, and amid a period characterized by excessive losses of Black and other minorities' lives, it initiated and released a study that attributes virtually all racial inequality to differences in geography and class. ${ }^{2}$

We begin by defining some key terms. We define institutional racism as existing when one racial/ethnic group is systematically disadvantaged in market and non-market allocations of income and wealth due to 'well-established practices, customs, and laws' (Vowels 1971, p. 6). ${ }^{3}$ Among these 'practices' are personal (taste-based) and 'rational' discrimination, which commonly occur even when legally prohibited (Dymski 1995). Structural racism arises when the members of one

\footnotetext{
${ }^{1}$ While the UK census designates $17 \mathrm{racial} /$ ethnic categories, most residents with partial or full ancestry from Black racial groups in Africa are denoted as either 'Black Caribbean' (which implicitly includes West Indians, even though not all West Indians self-identify as 'Caribbeans') or 'Black African'. We use these two designations. The term 'Black Briton' herein referring jointly to both of these populations. Following UK usage, the term 'Black American' here refers to Americans with partial or full ancestry from Black racial groups in Africa; 'Latino' denotes Americans with full or partial ancestry in Latin America.

${ }^{2}$ We put the situation of Black UK residents into comparative context with that of other non-white Britons where appropriate here. Simultaneously, we recognize that the UK terms 'non-white' and 'other minorities' reflect the 'confusion and ambiguity in usage' of official UK terms for race and ethnicity (Aspinall, 2002, p. 803). Since 'ethnic/racial terminology may be seen as a form of representation' (Aspinall, 2020, p. 1), these terms fall far short of adequate representation.

${ }^{3}$ The definitions suggested here rely not just on Vowels (1971), but on many other uses of these terms in the pages of this journal - in particular, Browne 1970, Handy 1993, Hill 1989, and Ellison 1996.
} 
racial/ethnic group systematically hold advantages in resources, income, and wealth relative to members of other groups. Structural discrimination - the systematic disadvantage of members of one group vis-à-vis others in market processes wherein success depends on financial, material, or human capital - is a consequence of structural racism. The comparative analysis of structural racism in the UK and the USA undertaken here emphasizes the differing historical sequences and circumstances of racial/ethnic minorities' entry into these countries, as well as the differing patterns of racial/ethnic concentration within the structure of employment. While acknowledging the importance of the behavioral patterns and organizational mechanisms that produce and reproduce racially different outcomes in markets, and thus comprise institutional racism, our focus in this paper is on explaining patterns of structural racism in the context of the pandemic.

Structural and institutional racism unfold within a larger political economic context encompassing class processes, micro and macro market mechanisms, and so on. We denote that larger frame as a racial formation. We adopt Harold Baron's definition of this term: a racial formation consists of 'four elements: (1) white racial group with its class characteristics; (2) black racial group; (3) racial control system; and (4) the dominant national mode of production' Baron (1985, p. 12). While Baron's definition must be adjusted to encompass situations in which multiple racial/ethnic minorities exist in majority-white nations, its strength is to show how evolving patterns of structural and institutional racism - what Baron calls the 'racial control system' - co-evolve with changes in the broader political economy.

Our core argument here is that the pattern of racially asymmetric losses and race-neutral policy responses to the two great megacrises of the 2000s is a manifestation of both countries' structural and institutional racism. Racial formations in the US and UK differ because of contrasting historical relationships to slavery and to global empire, but in both countries the consequence is that Black Britons and Americans (along with other ethnic minorities) are more exposed to losses that can be catastrophic in crisis periods. This excessive risk - of home foreclosures in the former circumstance, Covid-19 exposure today - derives from racial disparities in income, wealth, or access to housing that have been 'naturalized' over time, and now appear built into these nations' socio-economic foundations. As such, race-based gaps in the extent of financial or human loss are not prioritized for remediation: to the contrary, as illustrated by the coincidence of Covid-19 and of BLM protests in the UK. 
Section 2 summarizes the heightened vulnerability of Black Britons to Covid-19, including some comparisons with Black American experience. Section 3 shows how Black Britons' vulnerability can be traced directly to their historical insertion into a country with a distinctive racial formation. Section 4 shows how the impact of the subprime crisis on Black Americans and the failed governmental response to it exposes the positional power in the hub of the US racial formation. Section 5 then turns to the UK response to Covid-19. Rather than strongly countering Covid-19's racially-differential risks and impacts, the current UK government has justified its inaction by issuing a comprehensive report that redefines racism as a residual category decoupled from the very history responsible for those racial differentials. Section 6 concludes by exploring how to establish an ethical basis for policies that reduce or eliminate the racially-differential effects of 21 st century crises.

\section{The vulnerability of Black Britons to Covid-19: a systemic approach}

In the US, Black Americans make up 13\% of the population, but represent $30 \%$ of Covid- 19 infections, with hospitalization rates nearly three times higher than for whites (CDC, 2021) and death rates 2.4 times higher (Poteat et al., 2020). In the UK, age-adjusted differences between Black Britons and whites are shocking: Blacks are two to three times more likely than whites to have been diagnosed with Covid-19 (PHE, 2020), and are over four times more likely to die (White and Nafilyan, 2020). Black Britons accounted for $11 \%$ of those hospitalized with Covid-19 but over $36 \%$ of those admitted to critical care, after adjustment for age, sex and location (Harrison and Docherty, 2020). As of June 2020, Black and minority ethnic people accounted for $15.5 \%$ of all hospitalreported UK Covid-19 deaths (White and Nafilyan, 2020). Harrison and Docherty (2020) show that these ethnic differentials in Covid-19 mortality cannot be attributed to differences in health-seeking behaviors and genetic factors, and thus appear to be caused at least in part by socio-economic disadvantage.

One immediate cause of this disparate death and incidence toll is overrepresentation in 'frontline' occupations. Black and minority ethnic people make up $44 \%$ of the National Health Service (NHS) medical staff (ONS, 2020). Black African Britons comprise $2.2 \%$ of the working-age population, but $7 \%$ of all nurses (Platt and Warwick, 2020). Black Britons are overrepresented in low-wage healthcare and other essential ('key sector') work. A Black African Briton is 50\% more likely than a white Briton to be key-sector worker, and three times as likely to be a health and social care worker (Platt and Warwick, 2020). These imbalances translate to disproportionate deaths. Between March and April 2020, 63\% of all healthcare workers and 95\% of doctors who died of Covid were from 
Black and minority ethnic backgrounds (BMA, 2020). The effect of these disproportions has been magnified by shortages of personal protective equipment (PPE) for key-sector workers (Horton. 2020).

Black Britons' over-representation among workers in front-line industries is even more pronounced than for Black Americans. ${ }^{4}$ And beyond exposure to Covid-19 transmission in workplaces, Black Britons' unequal socio-economic status also creates heightened vulnerability to the pandemic. Before the pandemic, at 9\%, Black Britons had the highest unemployment rate across all ethnic groups (ONS, 2019). The pandemic has widened this gap: Black African and Black Caribbean men are 50\% more likely than white British men to be found in shut-down sectors (Platt and Warwick, 2020). In November 2020, 11.6\% of Black Britons were unemployed, more than double than the unemployment rate of whites; this figure rises to $27 \%$ for Black Britons between 16 and 24 years old (Foley, 2020).

Some $46 \%$ of the UK Black British population lives in poverty (Francis-Devine, 2020), compared with $19 \%$ of the white British population (Social Metrics Commission, 2020). Black Britons also have more limited financial buffers than do whites: less than $15 \%$ have savings sufficient to cover three months of income if dismissed from work, versus $41 \%$ of white British households (Platt and Warwick, 2020). Black Britons were also more likely than other ethnic groups to report financial difficulties during the pandemic, with a quarter of all respondents to a survey reporting problems in paying bills, making housing payments, and/or in getting by (Barnes and Hamilton, 2020). Under these conditions, Black Britons are less able to refuse work that entails hazardous conditions.

Wealth inequality also extends to housing: Black British families have the lowest rates of homeownership across all ethnic groups, and just under $20 \%$ live in deprived areas, the highest figure for any UK racial group (Haque et al., 2020). Housing-related risk also emanates from the inability to self-isolate, which stems from overcrowding: and while fewer than $2 \%$ of white British households in London have more residents than rooms, 16\% of Black African households do (MHCLG, 2018). Although overcrowding is not as prevalent for Black Caribbeans and West Indians, they nevertheless face the highest number of hospital deaths per capita.

\footnotetext{
${ }^{4}$ In the US, Black Americans represent $11.9 \%$ of all workers and $17.0 \%$ of frontline workers, including $17.5 \%$ of healthcare workers (Gould and Wilson, 2020).
} 
The aforementioned factors contributing to the lower socio-economic status of Black Britons reflect the process of institutional racism that defines the mechanisms of opportunity and advancement for Black communities in the UK. Institutional racism leading to greater Covid exposure operates directly and indirectly through other social channels, of course. Behind economic inequality is differential access to education: recent evidence shows that, as in the past, Black students (in both the US and the UK) are significantly impacted by the racial bias of their teachers (Chapman and Bhopal, 2019). Black Britons are 10 times more likely than whites to be stopped and searched by the police, the highest figure for any British racial group ethnicity (UK Home Office, 2019); and whereas only $3 \%$ of UK residents are Black Britons, the latter constitute $12 \%$ of all those held in prisons (Lammy Review, 2017). These channels of inequality lead to higher rates of co-morbidity for Black Britons, which also heightens their vulnerability to Covid-19 (Platt and Warwick, 2020). Racial inequality in medical treatment has also been documented (Ackerman, 2020).

\section{Black Britons and the UK racial formation}

Black Britons' circumstances reveal a pattern of structural racism. As in the US, Black households face inferior educational and employment opportunities than others, have worse access to healthcare, and often live in segregated, lower-income neighborhoods. This brings us to the question of what patterns of discrimination, control and neglect characterize Britain's racial formation. Two concepts originally introduced to analyze US racial-minority communities are adapted for use here.

The situation of the heavily segregated Black American and Latino populations in US cities was the focal point of the 'internal colony' debate, much of which unfolded on the pages of this journal in the early 1970s. ${ }^{5}$ At issue was whether these communities should be seen through the lens of the overall accumulation process, or did their spatial and temporal dynamics more closely parallel the extraction of surplus from former colonies and imperial possessions? Baron (1985) introduced the term 'racial formation' to 'reflect the distinctive position - at times almost an enclave - of the black community within the United States social formation,' wherein 'the control of its economic life has been exercised on a day-to-day basis by an indigenous white class' (p. 12). ${ }^{6}$ This racial formation is

\footnotetext{
${ }^{5}$ See, for example, Harris (1972) and Tabb (1974).

${ }^{6}$ Two years after Baron's article appeared, Omi and Winant (1987) published Racial Formation in the United States), without citing Baron's article. Since these authors developed an all-encompassing socio-economic and behavioral conception of racial power, we rely here on Baron's formulation, which focuses on the dynamics of economic accumulation.
} 
shaped by the interaction of a racial control system with a dominant national mode of production; at the same time, the agency of the Black community itself, together with shifts in the accumulation process, have led to continual transformation. For example, in 1971, Baron (1971) had argued that US inner cities' growth was explained, in part, by a 'demand for black labor.' Twenty-five years later, William Julius Wilson (1996) described Black American inner-city communities as the site of the 'new urban poor' isolated from the locus of jobs.

Turning to the UK, the historical context of the Black British population explains much about today's disparate Covid-19 outcomes. Black Britons have lived in Britain since Roman times, with significant presence from the 16th Century onward. By the late 1700s, the slave trade was flourishing, and there were as many as 30,000 Black Britons, many living as slaves. Slavery was abolished in Britain only in 1833. Except for higher numbers during the World War periods, the Black British population hovered near 10,000 residents in the 20th century until 1950. In the 1950s, the British government encouraged Commonwealth citizens to immigrate to the UK in order to rebuild the economy and fulfil labor shortages. This resulted in a large influx of Black African and Black Caribbean and West Indian workers, especially into the NHS and public sector transport services. A quarter of a million West Indians arrived in the 1950s. The higher concentration of minoritized ethnicities in these essential professions today, such as NHS nurses, is reflective of Black Britons being channeled into low-status low-income employment (Olwig, 2018). Key workers now considered indispensable to the coherence of societal life were previously considered to be lowskilled and expendable, which is reflective of inferior social status and a racialized position within the constructed racial hierarchy. In the context of the country's relative lack of experience of diversity in its population prior to World War II, bringing in migrant labor from the former colonial possessions prompted Black Britons to fit particular structural roles in the economy, without provisions for their overall wellbeing (in terms of e.g. access to housing or social services). One of the forms of structural racism in the UK thus arises because of the subordinate economic roles available to Black workers in the industries in which Black Britons have been concentrated.

Black Britons' multiple vulnerabilities to Covid-19, then, are rooted in their limited access to education, housing, and employment, linked to the circumstances of their entry (as 'replacement labour' (Phillips, 1998)) into the country. Indeed, while Black immigrants from former British colonies had the right of entry into the UK, their arrival as replacement labor was robustly opposed 
both by the 1945-1951 Labour government (Miles, 1989) and by the 1951-55 Conservative government (Carter et al., 1987). ${ }^{7}$

Black Briton's unique historical circumstances are linked to the creation of a UK racial formation very different from that in the US. Four differences between the historical conjuncture of UK and US Black settlement stand out. First, most Black descendants of slaves in the UK are there due to politically contested migration that began only after World War II. In the US, by contrast, this population's roots go back centuries. Second, while the US maintained strict limits on non-white immigration in the post-War period, Britain was accepting a surge of non-white immigrants from its former imperial possessions. Third, while both the US and UK saw significant Black migrations in the last century, the labor shortages that spurred them had very different triggers. The US's 'great migration' involved relocation within national borders and was caused primarily by World-War production booms and the slowdown of Europe-to-US immigration. Black migrants to the UK crossed national borders in response to post-1945 labor shortages. Fourth, Black Britons and Black Americans are integrated differently into domestic labor markets. Black Britons have higher measured employment rates than Black Americans, suggesting slightly higher integration overall. However, Black Britons' unemployment rate is higher than that for Black Americans, and they account for a greater percentage of the front-line Covid-19 workforce, also in relative terms against their population share (as previously discussed in Section 2). At the same time, in subordinate areas of health-care employment, such as nursing and home health aides, Black Americans are remarkably overrepresented. ${ }^{8}$

The first point of difference implies that while the UK has had an elaborate control system in place to oversee the overseas British empire since the $19^{\text {th }}$ Century, that system was not accompanied by a

\footnotetext{
${ }^{7}$ The continuing political currency of anti-Black feeling was more recently seen when, in 2014, thenHome Office Minister Theresa May authorized a wave of deportations targeting illegal immigrants. Caught in this dragnet were British residents who were part of the 'Windrush generation' (referring to the name of the ship transporting immigrants from Jamaica) six decades ago. An unknown number of these individuals were deported. These residents' status was put into question because an archive of old landing papers had been destroyed by the Home Office in 2010. Mrs. May issued a grudging apology in September 2018, at which time she was UK Prime Minister.

${ }^{8}$ The August 2021 Annual Population Survey for the UK finds that Black Britons account for 3.3\% of the overall UK labor force, with an employment rate of $69 \%$, and an unemployment rate of $8 \%$. By contrast, in the US, the December 2020 Bureau of Labor Statistics report provides corresponding figures of $13 \%, 62 \%$, and $6.2 \%$ for the US. According to the U.S. Department of Health and Human Services (2017), between 2011 and 2015 Black Americans accounted for 32\% of all nursing and home health-care aides.
} 
domestic regime focused on control and exploitation of a domestic enslaved or formerly enslaved Black population. The second and third points mean that Black Africans' and Black Caribbeans' and West Indians' migration to Great Britain coincided with large inflows of other non-white immigrants. The South Asian British population, less than 10,000 before World War II, grew dramatically after the Partition of India in 1947, also responding to the demand for labor needed to rebuild the UK after the War. This influx of non-white immigrants and refugees created a population control problem. This was nothing new for a nation that, as the cradle of the industrial revolution, had systematically facilitated the shift of millions of rural residents and of the Irish to rising urban manufacturing and trading cities, all without eliminating or asset-stripping its landed gentry and royalty.

In effect, a UK racial formation emerged in the post-War years. A multi-racial Britain came quickly into being, its shape guided by which industries and professions could be entered, and which communities were open to inflows of Black and Asian British residents. White workers whose families had provided cannon fodder for European wars and bodies for factories were soon cheek-byjowl with non-White residents in housing-short cities. Post-war growth did not keep pace with that of the US; indeed, the UK was forced to devalue its pound sterling in 1966. The racial dynamics of this evolving scenario, well described by stratification theory (Darity, 2005), saw a 'critical role assigned to relative group position as a basis for the development and maintenance of prejudicial beliefs about the "other".' (Darity et al., 2017, p. 40). In this context, 'discrimination is both rational and functional, albeit unfair and inequitable' in 'preserving or extending the relative status of the group' (ibid., p. 50). However, intergroup competition for status and jobs, supercharged by influxes of racialized newcomers, led to recurring episodes of civic unrest and race-related killings. From 1965 onward, in the shadow of the US civil rights movement and of decolonization, the UK Parliament began passing a series of laws making various forms of discrimination unlawful.

This racial formation was piecemeal, managed nationally by governments not dependent on Black and Asian British votes, and overseen more locally by sub-national 'authorities' whose budgets were centrally dictated by the sitting national government. All these parallels - their colonial origins, the timing of their entry, their assigned economic roles, and their electoral invisibility - resulted in distracted oversight. To cite one example, the UK's census of population has included questions about ethnicity only since 1991, and answers were initially self-reported. This data collection effort, combined with legal prohibition on discrimination by race, led to the creation of the term 'BAME' (Black, Asian, and other Minority Ethnic). This term, which describes no actual person and is 
commonly used in governmental reports and documents, perfectly summarizes the character of the UK racial formation: its core is the management of those whose services are needed, but whose specific places of origin are irrelevant.

\section{The Subprime Crisis and the Response to Structural Racism in the US}

Like the Covid-19 pandemic, the subprime crisis hit minority households hard, especially in the US, exposing these nations' legacies of structural and institutional racism. In the case of the UK, available evidence shows that Black African households in the UK own 10 times less wealth than white British families, and the wealth gap has increased since 2010 (Runnymede Trust, 2020). However, the proportion of homeowners holding subprime mortgage loans, $6 \%$ or 670,000 in total (Keasey and Veronesi, 2012), was much lower than in the US, as was the percentage of all mortgages foreclosed $(2.5 \%)$.

It was in the US that the subprime crisis fell like a hammer blow on minority communities. This was due in part to megabank-financed malfeasance and predatory credit-market practices that had aimed at Black American and Latino communities from their origin in the 1990s (Dymski, 2010). The crisis and the ensuing policy response disproportionately affected minority households (Dymski et al., 2013). But while extraordinary policy efforts were made to rescue the too-big-to-fail megabanks that had profited from subprime lending, governmental programs aimed at forestalling foreclosures were almost completely ineffective. ${ }^{9}$ The first tranche of expenditure from the $\$ 700$ billion Troubled Asset Relief Program (TARP) in October 2008, \$115 billion, was injected into 8 large banks. And while $\$ 50$ billion of TARP money was set aside for loan modification for 'underwater' homeowners, only a third of this amount was eventually spent, and only $22 \%$ of the 4 million households eligible for loans modification were served (Hudson, 2016). Banks rejected most modification requests.

Ultimately 12 million homes were foreclosed due to the subprime crisis; over half of these had been owned by Black Americans or Latinos (Bocian et al., 2010), who were far more likely than white borrowers to have been supplied with subprime - not prime - mortgage loans. More than $8 \%$ of all Black Americans and Latino homeowners lost their homes, versus 4.5\% of whites. As a result of this

\footnotetext{
${ }^{9}$ The UK government also bent over backwards to save its insolvent mega-banks; the UK's net public debt-to-GDP ratio doubled overnight in October 2008.
} 
disproportionate foreclosure rate, gains in net household wealth for minority households due to better pre-Great Recession access to credit evaporated as a result of that crisis.

At its pre-crisis peak, median net wealth of Black households was $\$ 27,790$ in 2004 and it nearly halved after the subprime crisis to $\$ 12,110$ in 2013 (U.S. Survey of Consumer Finances 2019). By 2019 , it was still well below the pre-crisis levels at $\$ 20,730$. The median net wealth of White households declined proportionately less relative to its pre-crisis peak, falling from \$201,480 in 2007 to $\$ 147,410$ in 2013 , reaching $\$ 181,440$ in 2019 .

However, the disparity of wealth losses was even starker at the intersection of gender and race. The median net worth of Black female-headed households more than halved in response to the crisis, from a peak of $\$ 14,780$ in 2004 to a post-crisis low of $\$ 6,910$ in 2016, and by 2019 it was still less than half of what it was in 2004 , at $\$ 7,220$. In contrast, median net wealth of White female-headed households fell from its peak of $\$ 112,370$ in 2007 to a post-crisis low of $\$ 70,340$ in 2010, reaching $\$ 86,550$ in 2019.

In sum, the US government's asymmetric policy response to the subprime crisis permitted global US megabanks to retain their leading role in global finance (Ioannou et al, 2019), while adding to US minority communities' vulnerability to the Covid-19 pandemic.

\section{The Covid-19 Pandemic and the Response to Structural Racism in the UK}

Given the disproportionate numbers of 'BAME' workers in the NHS and in other front-line occupations, the near-coincidence of the arrival of the Covid-19 pandemic with the BLM movement has given the Conservative-led UK government two contradictory political imperatives: the need to undertake 'conscious action to maintain hierarchies among social groups', as Ajilore (2019, p. 153) put it, and the need for national unity in the face of the global pandemic.

The sequence of events since the UK lockdown was announced on 23 March 2020 tells the story. The first four NHS doctors to die from Covid-19 were members of 'BAME' groups (Siddique, 2020); and as noted above, these groups accounted for the vast majority of NHS staff deaths in March and April 2020 (BMA, 2020). In April 2020, Labour Party leader Keir Starmer asked Doreen Lawrence, mother of murdered teen Steven Lawrence, to review evidence on the impact of Covid-19 on BAME communities. On 25 May 2020, George Floyd was murdered, and BLM protests occurred 
across the UK from 28 May to 21 June. In June, Prime Minister Johnson requested a ministerial analysis of 'disparities in risks and outcomes' for Covid-19. In July 2020, the Commission on Race and Ethnic Inequalities was formed, also in reaction to the BLM protests.

Doreen Lawrence's review, An Avoidable Crisis (www.lawrencereview.co.uk/), was released on 23 September 2020. It finds that the disproportionate impact of Covid-19 is due to 'structural inequality, inadequate protective measures and Government inaction'; its last chapter is entitled 'End structural racism'. A month later, on 22 October, the first Ministerial report attributed higher infection and mortality rates for BAME groups to 'socioeconomic and geographic factors, pre-existing health conditions' that 'were leading to higher infection and mortality rates for ethnic minority groups.' Recently appointed government spokesperson Raghib Ali, a clinical epidemiologist, told the British Medical Journal: "There is certainly no evidence ... that blacks and south Asians were treated any differently once they reached hospital. I don't think structural racism is a reasonable explanation. Those that put it forward need to provide evidence." (BMJ, 2020).

In the first three months of 2021, the UK government made some concessions to the mounting evidence that minorities faced higher Covid-19 risks; it allocated $£ 23 \mathrm{M}$ to localities to support those at special risk from COVID-19, and race/ethnicity as well as deprivation were named as Covid-19 risk factors both by the government's chief medical officer and by the second ministerial report. On 31 March 2021, the Commission on Race and Ethnic Inequalities released a 300-page report that took back this conceded ground. ${ }^{10}$ According to this document:

'The evidence shows that geography, family influence, socio-economic background, culture and religion have more significant impact on life chances than the existence of racism. ... we have argued for the use of the term 'institutional racism' to be applied only when deep-seated racism can be proven on a systemic level and not be used as a general catch-all phrase for any microaggression, witting or unwitting.' (p. 7)

The Commission complains of imprecise uses of terminology involving racism, and proposes a 'framework for different types of racism and racial disparities' that involves a two-step process: first, racial disparities should be divided into those that can be explained by non-racial factors such as those named above (geography, class, gender, culture, religion, and so on) and those that remain

\footnotetext{
${ }^{10}$ Bruce-Jones (2021) provides an excellent critical assessment of the Commission report.
} 
unexplained by those factors. Institutional racism is interpreted in this report as the existence of racist practices within an institution, while systemic racism is interpreted as racist outcomes resulting from the interaction of two or more institutions. The report admits that anything left over could be termed structural racism. However, the residual category called 'structural racism' is virtually predefined as an empty set.

Consequently, the occupational segregation that constitutes the primary source of the UK's racial/ethnic pay gap (Brynin and Güveli, 2012), and which itself is the result of the segmented labor-market access of non-white workers, falls outside of the categories identified in the Commission report. The Commission's emphasis instead falls squarely on socio-behavioral factors. The term 'cultural' appears 55 times in the Commission report, 'culture' 53 times; 'wealth', 12 times; and 'assets' only once (and there in reference to 'social assets'). A section entitled 'Cultural traditions, family and integration,' contains this passage:

'If it is possible to have racial disadvantage without racists then we need to look elsewhere for the roots of that disadvantage. Racial disadvantage often overlaps with social class disadvantage but how have some groups transcended that disadvantage more swiftly than others?' (p. 41)

In case the answer to this apparently naïve question escapes anyone, a paragraph later, the text reads, 'the Commission noted with great concern the prevalence of family breakdown', with specific references made to single-parent family prevalence among 'Black Caribbean' and 'Black Other ethnic' households. ${ }^{11}$

In essence, then, the Johnson government, when presented with evidence of racially disparate Covid19 outcomes and confronted in UK streets with massive protests calling for racial justice, responded with a textbook case of the aggressive protection of self-interest delineated by stratification theory. ${ }^{12}$

\section{Conclusion}

${ }^{11}$ The Commission report repeats many of the arguments made by Thomas Sowell $(1981,1983)$ in the 1980s. The devastating critiques of these books published in the Review of Black Political Economy, by Chachere (1983) and Williams (1984) apply with full force to this 2021 report.

${ }^{12}$ Several Commission members and staff have alleged that the Commission report was rewritten after it was delivered to 10 Downing Street - that is, Prime Minister Johnson's office - prior to its release (Iqbal, 2021). 
Black Britons, like Black Americans, have suffered greater economic losses in the Covid-19 pandemic than have other UK residents, and have had double the rate of Covid-induced mortality. This reflects both populations' systematically subordinate place in economy and society, one that is shared with other ethnic-racial groups. Having developed over long periods intertwined, if differently, with histories of slavery and colonialism, this structural racism has been naturalized. This 'naturalization' provides a ready justification for maintaining and even publicly rationalizing the class and other privileges built into the current racial formation, as has been done explicitly during the pandemic in the UK. In a global financial crisis or an international pandemic, the privileged group's defense of its own domestic place can be dressed up as protecting the national interest. The privileged group is simply doing 'what has to be done': a naked appeal to self-interest, much less an articulation in racialized us-versus-them terms, is not required.

Yet even while these $21^{\text {st }}$-Century crisis episodes have generated more adverse outcomes for Black households in these two nations, they have also exposed the limits of the political will to recognize these logics, much less to remake them. There is, nonetheless, a case to be made for redress. Wolff and de Shalit (2007) show how a coherent ethical case for compensation for wrongs done in complex social circumstances can be built. And since the racially-disparate experiences of vulnerability and loss in question are rooted in practices of slavery and coerced labor that underlay the economic development of both nations, the question of reparations for slavery emerges. ${ }^{13}$ Undoing these legacies would require actions cutting across multiple realms of social and economic life precisely because racial inequality is built into both societies' logics of social reproduction. The timing is, in one sense, inconvenient in that both crises have generated society-wide costs. But the very scope of these crises has now put the legitimacy of governments in power into question. Perhaps the moment for sustained debate and public action addressing injustices that lie at the root of these two democracies has arrived.

\section{References}

Ackerman, N. (2020, August 18). Teaching doctors to watch for patients going blue is racist, leading medical school says. London Evening Standard.

\footnotetext{
${ }^{13}$ Reddie (2020) and Wardle and Obermuller (2019) discuss the case for reparations for the 'Windrush generation'.
} 
https://www.standard.co.uk/news/uk/patients-turning-blue-racist-medical-schoola4527266.html

Aspinall, P.J. (2002). Collective Terminology to Describe the Minority Ethnic Population: The Persistence of Confusion and Ambiguity in Usage. Sociology 36(4): 803-816.

Aspinall, P.J. (2020). Ethnic/Racial Terminology as a Form of Representation: A Critical Review of the Lexicon of Collective and Specific Terms in Use in Britain. Genealogy 4(3), 87: 1-14.

Barnes, A. and Hamilton, M. 2020. Coronavirus and the social impacts on different ethnic groups in the UK: 2020. Available at:

https://www.ons.gov.uk/peoplepopulationandcommunity/culturalidentity/ethnicity/articles/co ronavirusandthesocialimpactsondifferentethnicgroupsintheuk/2020 [Accessed 2nd May 2021]

Baron, Harold M. (1971). The Demand for Black Labor: Historical Notes on the Political Economy of Racism. Cambridge, MA: Radical America.

Baron, Harold M. (1985). Racism Transformed: The Implications of the 1960s. Review of Radical Political Economy 17(3): 10-33.

BMA. (2020). COVID-19: the risk to BAME doctors. Available at: https://www.bma.org.uk/adviceand-support/covid-19/your-health/covid-19-the-risk-to-bame-doctors [Accessed 2nd May 2021]

BMJ. (2020). Covid-19: Increased risk among ethnic minorities is largely due to poverty and social disparities, review finds. Available at: https://doi.org/10.1136/bmj.m4099 [Accessed 6th May 2021]

Browne, R.A. (1970). Toward an Overall Assessment of Our Alternatives. Review of Black Political Economy 1(1), March: 18-26.

Bruce-Jones, E. (2021). The United Kingdom on Race: A Warning for Europe. 13 April. Blogpost accessed on 2 May 2021 at https://verfassungsblog.de/uk-racism/.

Carter, B., C. Harris, and S. Joshi. (1987). The 1951-55 Conservative Government and the Racialisation of Black Immigration. Policy Papers in Ethnic Relations No. 11. University of Warwick: Centre for Reseearch in Ethnic Relations. October.

CDC 2021. Risk for COVID-19 Infection, Hospitalization, and Death By Race/Ethnicity. Available at: https:/www.cdc.gov/coronavirus/2019-ncov/covid-data/investigationsdiscovery/hospitalization-death-by-race-ethnicity.html [Accessed 2nd May 2021] 
Chachere, B. (1983). The Economics of Thomas Sowell: A Critique of "Markets and Minorities". Review of Black Political Economy 12(2), Winter: 163-74.

Chapman, T.K. and Bhopal, K. (2019). The perils of integration: exploring the experiences of African American and black Caribbean students in predominately white secondary schools. Ethnic and Racial Studies, 42(7), 1110-1129. https://doi.org/10.1080/01419870.2018.1478110

Darity, Jr., W. (2005). Stratification economics: The role of intergroup inequality. Journal of Economics and Finance. 29(2), 144-153.

Darity, Jr., Hamilton, D., Mason, P.L., Price, G.N., Davila, A., Mora, M.T., and Stockly, S.K. (2017). Stratification economics: A general theory of intergroup inequality. In Flynn, A., Holmberg, S.R., Warren, D.T., and Wong, F.J. (Eds.), The Hidden Rules of Race: Barriers to an Inclusive Economy (pp.). Cambridge University Press.

Dymski, G. (1995) The theory of Bank Redlining and Discrimination: An Exploration. Review of Black Political Economy 23(4), 1995: 37-74.

Dymski, G. (2010). From Financial Exploitation to Global Instability: Two Overlooked Roots of the Subprime Crisis. In Konings, M. (Ed.), The Great Credit Crash (pp.72-102). Verso Press.

Dymski, G., Hernandez, J., and Mohanty, L. (2013). Race, Gender, Power, and the Subprime/Foreclosure Crisis: A Meso Analysis. Feminist Economics, 19(3), 124-51.

Ellison, J. (1996). Commons-Mitchell-Myrdal-Polanyi Institutionalism: A Review of 'Inequality: Radical Institutionalist Views on Race, Gender, Class, and Nation'. Review of Black Political Economy, 25(2), Fall: 103-125.

Foley, N. 2020. Unemployment by ethnic background. House of Commons Library Briefing Paper Number 6385.

Gould, E. and Wilson, V. (2020) Black workers face two of the most lethal pre-existing conditions for coronavirus_-racism and economic inequality. Economic Policy Institute.

Haque, Z., L. Becares, and N. Treloar. (2020). Over-Exposed and Under-Protected: The Devastating Impact of COVID-19 on Black and Minority Ethnic Communities in Great Britain. London: Runnymede Trust.

Harris, D.J., 'The Black Ghetto as Colony: A Theoretical Critique and Alternative Formulation,' Review of Black Political Economy 2(4), 1972: 3-33. 
Harrison, E. et al. (2020). Ethnicity and Outcomes from COVID-19: The ISARIC CCP-UK Prospective Observational Cohort Study of Hospitalised Patients. http://dx.doi.org/10.2139/ssrn.3618215

Hill, R.B. (1989). Economic Forces, Structural Discrimination and Black Family Instability,' Review of Black Political Economy 17(3), Winter: 5-23.

Horton, R. (2020). Offline: COVID-19 and the NHS-“a national scandal”. The Lancet, 395(10229). https://www.thelancet.com/journals/lancet/article/PIIS0140-6736(20)30727-3/fulltext

Ioannou, S., D. Wójcik, and G. Dymski. (2019). Too-Big-To-Fail: Why Megabanks Have Not Become Smaller Since the Global Financial Crisis?," Review of Political Economy 31(3), July: 356-381.

Iqbal, Nosheen. (2021). Downing Street rewrote 'independent' report on race, experts claim. The Guardian, 29 April.

Keasey, K., and G. Veronesi. (2012). The Significance and Implications of Being a Subprime Homeowner in the UK. Environment and Planning A 44(6): 1502-1522.

Lammy Review. (2017). Lammy Review: final report.

https://www.gov.uk/government/publications/lammy-review-final-report

Miles, R. (1989). Nationality, Citizenship, and Migration to Britain, 1945-1941. Journal of Law and Society 16(4), Winter: 426-442.

Ministry of Housing, Communities and Local Government (MHCLG). (2020). Overcrowded households. 9 September. Accessed on 4 May at https://www.ethnicity-factsfigures.service.gov.uk/housing/housing-conditions/overcrowded-households/latest.

Office for National Statistics. (2019). Unemployment. https://www.ethnicity-factsfigures.service.gov.uk/work-pay-and-benefits/unemployment-and-economicinactivity/unemployment/

Office for National Statistics. (2020). NHS workforce. https://www.ethnicity-factsfigures.service.gov.uk/workforce-and-business/workforce-diversity/nhs-workforce/latest

Omi, M. and H. Winant. (1987). Racial Formation in the United States: From the 1960s to the 1980s. New York: Routledge \& Kegan Paul.

Olwig, K. (2018). Female immigration and the ambivalence of dirty care work: Caribbean nurses in imperial Britain. Ethnography, 19(1), 44-62. 
Phillips, D. (1998). Black Minority Ethnic Concentration, Segregation and Dispersal in Britain. Urban Studies 35(10): 1681-1702.

Platt, L. and Warwick, R. (2020). Are some ethnic groups more vulnerable to COVID-19 than others? The Institute for Fiscal Studies.

Poteat, T., Millett, G. A., Nelson, L. R. E., and Beyrer, C. (2020). Understanding COVID-19 risks and vulnerabilities among black communities in America: the lethal force of syndemics. Annals of epidemiology, 47, 1-3. https://doi.org/10.1016/j.annepidem.2020.05.004

Public Health England (PHE) (2020). Disparities in the risk and outcomes of COVID-19. https://assets.publishing.service.gov.uk/government/uploads/system/uploads/attachment_data /file/908434/Disparities_in_the_risk_and_outcomes_of_COVID_August_2020_update.pdf\#p age $=42$

Reddie, A. (2020). Racial Justice for the Windrush Generation in Great Britain. The Ecumenical Review 72(1), January: 73-90.

Siddique, Haroon, 'UK doctors' coronavirus deaths highlight crucial role of BAME medics,' The Guardian 3 April 2020.

Social Metrics Commission. (2020). Measuring Poverty. https://socialmetricscommission.org.uk/wpcontent/uploads/2020/06/Measuring-Poverty-2020-Web.pdf

Sowell, T. (1981). Markets and Minorities. New York: Basic Books.

Sowell, T. (1983). The Economics and Politics of Race: An International Perspective. New York: William Morrow.

Tabb, W.K. (1974). 'Marxian exploitation and domestic colonialism: A reply to Donald J. Harris,' Review of Black Political Economy 4(4): 69-87.

UK Home Office. (2019). Police powers and procedures, England and Wales year ending 31 March 2019.

https://assets.publishing.service.gov.uk/government/uploads/system/uploads/attachment_data /file/841408/police-powers-procedures-mar19-hosb2519.pdf

U.S. Department of Health and Human Services. (2017). Sex, Race, and Ethnic Diversity of U.S, Health Occupations (2011-2015), Health Resources and Services Administration and National Center for Health Workforce Analysis, Rockville, Maryland. 
Vowels, R. (1971). The Political Economy of American Racism - Nonblack Decision-Making and Black Economic Status. Review of Black Political Economy 1(4), Summer: 3-39.

Wardle, H., and L. Obermuller. (2019). "Windrush Generation" and "Hostile Environment": Symbols and Lived Experiences in Caribbean Migration to the UK. Migration and Society: Advances in Research 2: 81-89.

White, C. and Nafilyan, V. (2020). Coronavirus (COVID-19) related deaths by ethnic group, England and Wales: 2 March 2020 to 10 April 2020. Office of National Statistics

Williams, R. (1984). "The Economics and Politics of Race: An International Perspective" by Thomas Sowell. Review of Black Political Economy 13(1), Summer: 201-204.

Wilson, W.J. (1996). When Work Disappears: The World of the New Urban Poor. New York: Alfred A. Knopf.

Wolff, J. and de Shalit, A. (2007). Disadvantage. Oxford University Press. 